\title{
PROSES LAY OUT KORAN DI HARIAN REPUBLIKA
}

\author{
Danang Arya Prayoga \\ Program Studi Penerbitan, Jurusan Penerbitan \\ Politeknik Negeri Media Kreatif Jakarta
}

\begin{abstract}
There are many things that need to be prepared in the process of publishing daily newspapers, starting from preparation of texts, photos, illustrations, until the process of distribution. This research describes the layout process in Republika. The layout process plays an important role in the look of a newspaper. In the process layout, there are some people who are involved, namely, managing editor, editor, photo editor, and stylist layout. Based on the experience of industry practices, everyone associated with the potentially problematic atak process so that it can interfere with the smooth running of the process say. The problem will be more severe if insufficient layout styling using software related to duties and responsibilities.
\end{abstract}

Keywords: Layout, Republika, Adobe InDesign

\section{PENDAHULUAN}

Dalam sebuah penerbit, ada bagian pengatakan yang berkaitan dengan penataan letak naskah, foto, dan ilustrasi yang sudah mengalami proses editing sebelumnya. Sebelum masuk ke bagian percetakan tentunya naskah, foto, dan ilustrasi harus ditata terlebih dahulu oleh penata letak, agar terlihat rapi, seimbang, dan nyaman dibaca. Perwajahan atau tata letak adalah penataan unsur-unsur desain grafis dalam sebuah media sehingga secara keseluruhan media tersebut menjadi tampil lebih menarik dengan komposisi yang seimbang.

Sama seperti semua media cetak, koran juga memiliki perwajahan atau tata letaknya sendiri. Seperti juga perwajahan pada media cetak lainnya, pada koran perwajahan juga dimaksudkan untuk alat bersaing saat dijajarkan di etalase bersama dengan media cetak yang lain karena halaman awal adalah bagian pertama yang dilihat oleh konsumen. Selain itu, dari halaman awal (kover depan) calon konsumen juga dapat melihat sekilas pesan yang ingin disampaikan oleh redaksi. Dengan cara ini juga redaksi akan dapat membentuk karakter dari media yang diwakilinya sehingga mudah untuk dikenali oleh pembacanya.

Perwajahan sangat berkaitan dengan tata letak atau atak (layout). Istilah atak sering disamakan dengan mendesain karena mendesain menekankan sebuah 
sudut pandang. Untuk membuat suatu desain, biasanya kita akan memulainya dari material-material dasar. Membuat sebuah atak yang baik, kita harus mengenal dahulu material-material dasar dalam desain dan atak. Material dasar desain disebut sebagai elemen desain sedangkan material dasar atak disebut elemen atak.

Elemen-elemen desain meliputi garis (line), bentuk (shape), tekstur, ruang sisa (space), ukuran (size), nilai (value) dan warna. Semua elemen desain ini sebenarnya sudah kita kenal dalam kehidupan sehari-hari, jadi bukan hal yang sama sekali baru. Adapun elemen layout meliputi elemen teks, elemen visual, dan invisible elemen. Atak juga memiliki prinsip, antara lain: urutan, penekanan, keseimbangan, kesatuan, dan konsistensi.

Dalam mengatak, ada beberapa cara yang harus diperhatikan agar dapat mengatak dengan cepat, rapi, dan seimbang. Penata letak harus mengikuti gaya selingkung divisi desain perusahaan, menuangkan kreativitas agar desain atak terlihat menarik, juga menghafal tombol untuk memilih parameter di aplikasi Adobe InDesign. Pada saat praktik industri, penulis menemukan beberapa masalah dalam mengatak. Di antaranya, naskah yang sedikit, kiriman foto yang banyak, penempatan foto dan naskah, banyaknya karakter naskah dari redaktur, ketidaksetujuan redaktur dalam desain layout yang sudah dibuat, dan sebagainya. Oleh karena itu, dalam pembahasan penelitian ini, penulis akan membahas tentang proses atak koran di Harian Republika.

Buku

Pengetahuan

Penerbitan karya Nova Darmanto (2007: 22) menjelaskan bahwa penerbitan merupakan kegiatan yang memerlukan proses yang panjang. Kegiatan penerbitan akan melibatkan banyak waktu dan orang. Sebagai kegiatan proses, ilmu penerbitan tidak berdiri sendiri karena memerlukan beberapa keahlian intelektual yang terlibat dalam proses penerbitan. Penerbitan merupakan kegiatan intelektual dan profesional dalam menyiapkan, menyunting, dan menghasilkan berbagai jenis publikasi, kemudian memperbanyak dan menyebarluaskan untuk kepentingan umum.

Kegiatan penerbitan secara eksternal merupakan sentral dari seluruh komponen industri buku, komunikasi atau sejenisnya. Pengarang, percetakan, toko buku, perpustakaan, menjadi rekan kerja penerbitan. Dalam industri buku mereka menjadi kelompok yang menggerakkan kegiatan industri buku sedangkan secara internal penerbit atau penerbitan terdiri atas bagian-bagian utama seperti editor, produksi, pemasaran, dan distribusi serta bagian administrasi keuangan.

Dalam sebuah penerbit, ada beberapa bagian yang mempunyai 
tugas dan peranan yang berbeda. Tugas Akhir ini membahas peranan penata letak di sebuah penerbit koran Harian Republika. Hubungan antara penerbit dengan penata letak ialah naskah dan foto yang sudah diedit sebelumnya, diatak naskah dan fotonya oleh penata letak. Hal tersebut dilakukan untuk menyeimbangkan naskah dan foto agar telihat menarik dan enak dipandang sehingga pembaca tidak bosan membaca naskah itu. Akan tetapi, gaya selingkung dan aturan dalam mengatak harus diikuti untuk konsistensi terhadap desain atak.

Atak adalah komposisi, tata letak, tata letak huruf yang akan dicetak. Kasarnya berbagai unsur karya seni (teks, gambar, foto, dan ilustrasi lain) yang disatukan dan diletakkan pada satu lembaran karton, kemudian difoto untuk dijadikan separasi. Mengatak mengatur tata letak huruf yang akan dicetak, mengatur (menata) sesuai dengan komposisi yang baik. Pengatakan adalah proses cara atau perbuatan mengatak. Atak juga dapat didefinisikan sebagai usaha untuk menyusun, menata atau memadukan unsurunsur komunikasi grafis (teks, gambar, tabel, dan sebagainya) menjadi media komunikasi visual yang komunikatif, estetik, dan menarik. (Hendi Hendratman: 2006).

Selain itu, layout juga berfungsi sebagai alat komunikasi media untuk pembaca. Komunikasi tata letak berarti mendistribusikan informasi yang berbeda untuk berbagai kegunaan, membutuhkan penggunaan media yang berbeda. Jadi, atak juga memberikan pesan tersendiri untuk pembaca. Banyak sekali kemungkinan jenis atak, tetapi intinya atau yang biasa dipakai adalah layout dengan menggunakan format atau sumbu (Hendi Hendratman: 2006), yaitu (1) Format Horizontal, (2) Format Vertikal, (3) Format Diagonal, (4) Format Radial, (5) Format Acak atau Scatter.

Ada bebarapa hal yang harus dipersiapkan untuk menata letak dengan menggunakan Adobe InDesign, yakni

1. Pengambilan naskah, foto, dan illustrasi. Penata letak harus mengetahui letak file yang akan diambil agar dapat mengambil file dengan cepat dan dapat langsung mengatur naskah di area layout.

2. Mengatur ukuran atak (ukuran kertas, margin, colomn, dan gutter).

3. Mengatur sesuai dengan persetujuan gaya selingkung agar semua jarak terlihat rapi.

4. Membuat dummy.

5. Menghitung jumlah karakter pada area kotak teks yang akan dimuat naskah agar naskah tidak melebihi area naskah yang disediakan.

6. Membuat paragraph style. Membuat komponen teks yang akan dipublikasikan. Mengatur Font, Font Family, Size, 
Leading, Kerning, Tracking, $\mathrm{H} / \mathrm{V}$ Scale, Baseline Shift, Color, Alligment, Left Indent, First Line Indent, Space Before, Space After, Drop Cap, Align to Grid, Hypernate, Line, dan sebagainya.

Atak memiliki banyak sekali elemen yang mempunyai peran yang berbeda-beda dalam membangun keseluruhan atak. Untuk membuat atak yang optimal, desainer perlu mengetahui peran masing-masing elemen tersebut (Surianto Rustan: 2009) yakni sebagai berikut.

1. Elemen Teks

(1) Judul (Headline)

Suatu artikel biasanya diawali oleh sebuah atau beberapa kata singkat yang disebut judul. Judul diberi ukuran besar untuk menarik perhatian pembaca dan membedakannya dari elemen atak lainnya.

(2) Deck/Lead/Taiching

Gambaran singkat yang dibicarakan di bodytext. Letaknya bervariasi, tetapi biasanya di antara judul dan bodytext.

2. Elemen Visual

(1) Foto

Suatu deskripsi visual yang menunjang kekuatan dari naskah atau artikel.

Kekuatan terbesar dari fotografi pada media periklanan khususnya adalah kredibilitasnya atau kemampuan untuk memberi kesan dapat dipercaya.

(2) Artworks

Segala jenis karya seni bukan fotografi baik berupa ilustrasi, kartun, sketsa, dan lainnya yang dibuat baik secara manual maupun dengan aplikasi komputer.

(3) Infographics

Fakta-fakta dan data statistik hasil dari survei dan penelitian yang disajikan dalam bentuk grafik (chart), tabel, diagram, peta, dan sebagainya.

(4) Garis

Elemen desain yang dapat menciptakan kesan estetis pada suatu karya desain. Di dalam atak, garis mempunyai sifat yang fungsional, antara lain membagi suatu area, penyeimbang berat dan sebagai elemen pengikat sistem desain supaya terjaga kesatuannya.

(5) Kotak

Berisi artikel yang bersifat tambahan atau suplemen dari artikel utama. Jika letaknya di pinggir halaman disebut sidebar. Elemenelemen visual juga sering diberi kotak supaya terlihat rapi.

(6) Inzet

Elemen visual berukuran kecil yang diletakkan di dalam elemen visual yang 


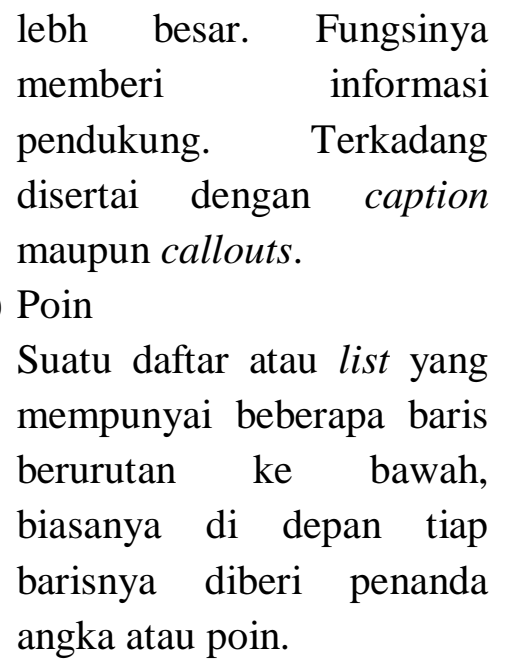

3. Elemen Tidak Terlihat (Invisible Element)

Elemen ini adalah yang terpenting dalam atak. Elemen ini menentukan letak elemen visual dan teks berada. Dengan bantuan elemen invisible atak akan menjadi hasil yang baik nantinya. Elemen ini merupakan pondasi atau kerangka yang berfungsi sebagai acuan penempatan semua elemen atak lainnya.

(1) Margin

Ruang antara tepi bidang penulisan dengan tepi kertas (halaman). Jarak antara pinggir kertas dan ruang yang akan ditempati elemen-elemen atak. Margin mencegah agar elemen-elemen atak tidak terlalu jauh ke pinggir halaman. Batas margin ditandai dengan garis berwarna merah muda, yang mengelilingi halaman dan membentuk bidang tulis. (Djoko Pramono: 2001)
(2) Grid

$\begin{array}{lr}\begin{array}{l}\text { Alat bantu yang } \\ \text { bermanfaat }\end{array} & \begin{array}{r}\text { sangat } \\ \text { dalam }\end{array} \\ \text { mengatak. } & \text { Grid } \\ \text { mempermudah } & \text { untuk } \\ \text { menentukan letak elemen } & \text { layout, memperhatikan } \\ \text { konsistensi, dan kesatuan } \\ \text { layout. }\end{array}$

Koran (dalam bahasa Belanda: krant sedangkan dalam bahasa Perancis: courant) atau surat kabar adalah suatu penerbitan yang ringan dan mudah dibuang, biasanya dicetak pada kertas berbiaya rendah yang disebut kertas koran, yang berisi beritaberita terkini dalam berbagai topik. Topiknya bisa berupa even politik, kriminalitas, olahraga, tajuk rencana, cuaca. Surat kabar juga biasa berisi karikatur yang biasanya dijadikan bahan sindiran lewat gambar berkenaan dengan masalah-masalah tertentu, komik, TTS dan hiburan lainnya. Ada juga surat kabar yang dikembangkan untuk bidang-bidang tertentu, misalnya berita untuk politik, properti, industri tertentu, penggemar olahraga tertentu, penggemar seni atau partisipan kegiatan tertentu.

Menurut KBBI, tipografi adalah ilmu cetak, seni percetakan. Juga dapat diartikan dengan ilmu yang mempelajari tentang huruf. Dengan perkembangan huruf-huruf di komputer, kita akan leluasa memilih jenis huruf yang diinginkan. Namun memilih jenis huruf merupakan pekerjaan yang 
melelahkan, karena banyaknya jenis huruf yang tersedia. Meski begitu, akan lebih mudah mengetahui lebih dahulu jenis-jenis huruf dan anatominya.

Setiap bentuk huruf mempunyai keunikan. Namun intinya tetap dalam batas-batas tertentu seperti body size, baseline, meanline, $x$-height, descender, dan ascender.

Hal yang terpenting dalam menentukan besar leading atau jarak antar baris adalah jangan sampai descender huruf di baris atas terhimpit dengan ascender huruf digaris bawahnya, terutama untuk bodytext, kecuali konsep desainnya mengharuskan demikian. Lebar paragraf juga mempengaruhi besar leading. Makin besar paragraf (semakin banyak teks dalam satu baris). Makin besar ukuran leading yang diperlukan untuk memudahkan pembaca mencari baris baru dibawahnya. Namun untuk paragrapf yang sempit di bawah rata-rata seperti pada caption, disarankan mempunyai leading yang cukup besar.

Software pengolahan kata dan softwere grafis pada umumnya selalu menyediakan pemilihan jenis huruf dan karakteristik, seperti: normal, tebal (bold), miring (italics), garis bawah (underline), dan kombinasi lainnya.

1. Huruf Miring (Italics): huruf italic akan menarik mata karena kontras dengan teks normal.
2. Huruf Tebal (Bold): huruf tebal juga mengundang perhatian karena kontras dengan huruf normal.

3. Huruf Bergaris Bawah (Underline): garis bawah menandakan adanya suatu yang "penting". Biasa dipakai pada hyperlink di web.

4. Huruf Berwarna: cara membedakan teks dapat menggunakan warna, meskipun tidak sekuat bold..

5. Huruf Kapital: huruf kapital dapat diartikan sebagai "perintah" atau "amarah". Jika mengirim pesan dengan huruf kapital, bisa diartikan posisi orang tersebut sedang marah.

Di samping transformasi dasar yang sederhana, agar lebih detail dan menarik, bisa ditambah kombinasi efek sebagai make-up. Dengan mengetahui karakteristik perataan-perataan tersebut dapat membuat audience menangkap informasi dengan mudah, cepat, jelas, dan menarik atau estetis.

1. Rata Kiri

Rata kiri paling mudah dibaca karena mata akan mudah menangkap saat membaca baris berikutnya.

2. Rata Tengah

Meskipun bentuknya secara menyeluruh tidak enak dipandang, rata tengah akan lebih sulit dan lebih lambat untuk dibaca.

3. Rata Kanan 
Rata kanan juga sulit dibaca, karena terbiasa membaca dari kiri ke kanan..

4. Rata Kiri Kanan

Rata kiri kanan mudah dibaca. Spasi antar huruf dan antar kata aka nada perubahan karena penyesuaian dengan perataan kanan.

5. Rata Kiri Kanan Penuh

Hampir sama dengan rata kiri kanan, namun dapat menimbulkan spasi antar huruf yang sangat ekstrim sehingga terlihat agak ompong.

Teks berupa daftar seperti daftar isi, menu, kerangka, dan point-point penting pada presentasi, perlu ada penekanan, antara lain:

1. Bullet and Numbering, memberikan objek atau angka atau penomoran pada awal baris.

2. Drop Caps, mengubah ukuran atau jenis huruf pada awal baris.

3. Objek Antara, memberikan objek antar baris.

4. Objek Latar Belakang, memberikan objek dibelakang teks pada setiap baris.

5. Transformasi, memberikan perubahan transformasi berupa PRS (Posisi Rotasi Skala).

6. Property Warna, memberikan warna disetiap barisnya.

\section{METODE PENELITIAN}

Metode yang penulis gunakan dalam penelitian ini adalah seperti berikut.

1. Kajian Pustaka

Metode ini dilakukan dengan mencari informasi melalui buku- buku referensi yang relevan dengan penjelasan masalah yang diteliti. Selain dengan media cetak, media online juga membantu dalam pencarian teori. Metode ini dilakukan dengan menjelajahi dunia maya dan mengumpulkan informasi yang tersebar di seluruh dunia dengan memanfaatkan alat pencarian data yang tersambung melalui jaringan internet.

2. Observasi

Metode ini dilakukan dengan cara menilik dan mempraktikkan langsung proses atak saat mendesain sebuah halaman, pada saat praktik industri bulan Februari hingga Maret.

3. Wawancara

Penulis mendapatkan data dan informasi dari pekerja Harian Republika, yakni Bapak Desi Purwo Wijianto disaat praktik industri berlangsung. Informasi yang didapat ialah tentang caracara mengatak berdasarkan gaya selingkung.

\section{HASIL DAN PEMBAHASAN}

\section{Profil Perusahaan}

Republika adalah koran nasional yang dilahirkan oleh kalangan komunitas muslim bagi publik di Indonesia. Penerbitan tersebut merupakan puncak dari upaya panjang kalangan umat Islam, khususnya para wartawan profesional muda yang dipimpin oleh eks wartawan Tempo, Zaim Uchrowi yang telah menempuh berbagai langkah. Kehadiran Ikatan 
Cendekiawan Muslim Indonesia (ICMI) yang saat itu diketuai BJ Habibie dapat menembus pembatasan ketat pemerintah untuk izin penerbitan saat itu memungkinkan upaya-upaya tersebut berbuah. Republika berdiri sejak 4 Januari 1993, pastinya mempunyai sejarah untuk pembentukan perusahaan ini.

Sejarah Republika bermula pada 7 Desember 1990. Pada saat itu berdiri sebuah organisasi beranggotakan intelektual Islam bernama Ikatan Cendikiawan Muslim se-Indonesia. Organisasi yang berdiri di Malang itu memilih B.J. Habibie sebagai ketua umum didampingi sekertaris umum, Wardiman Djojonegoro. Pengurus dan anggotanya adalah para intelektual muslim dengan profesi beragam, ada dosen, pejabat, pengusaha, LSM, dan lain-lain.

ICMI diharapkan mampu menjadi garda depan dalam penguatan posisi orang Islam dalam berpartisipasi membangun bangsa ini. Prinsipnya: umat Islam harus berada di tengah, bukan lagi di pinggir. Apalagi dilihat dari integritas dan kapasitas intelektual, tak sedikit kader muslim yang layak menjadi pemimpin-pemimpin di negeri ini. Dalam waktu tak lama, ICMI sedikit banyak telah mendorong umat menuju ke tengah. ICMI sebagai wadah intelektul umat Islam melihat bahwa keseimbangan informasi merupakan kebutuhan mutlak bagi perkembangan umat Islam. Maka diskusi di dalam pengurus ICMI untuk menerbitkan sebuah media intens dilakukan.

Rencana awal penerbitan media sendiri mulai dibahas dalam Silaturahmi Kerja Nasional (Silaknas) 1 ICMI di Jakarta 5-7 Desember dan kemudian masuk dalam program kerja. Pada awal tahun 1992, diskusi sudah mengerucut pada penerbitan koran. Disadari bahwa sudah ada media yang memprentasikan umat Islam, yakni koran Pelita dan majalah Panji Masyarakat. Koran Pelita terbit sejak 1974 dan menjadi alternatif koran Islam sejak dibredelnya harian Abadi. Kabarnya oplah Pelita sempat menembus 200 ribu. Pada 1979 Pelita dibredel bersama koran lain seperti Kompas dan Sinar Harapan. Terjadilah penggabungan kelompok intelektual Muslim dan profesional media. Merger antara ICMI dan mantan pengelola Berita Buana. Merger antara pemikir dan praktisi. Meskipun siap merger, tapi setiap personel belum banyak mengena.

Dari kalangan ICMI hanya beberapa yang kenal dengan awak mantan Berita Buana. Akhirnya, semua mantan Berita Buana untuk level kepala bagian ke atas dan semua wartawan di rekrut untuk bergabung di Republika. Sebagai suatu perusahaan yang bergerak di bidang media dan distribusi informasi untuk melayani masyarakat, berita yang disajikan adalah berbagai informasi penting 
dari dalam dan luar negeri, otomatis seluruh berita yang pernah dimuat dan ditampilkan, baik dalam bentuk tercetak maupun online adalah aset terpenting yang dimiliki Republika.

\section{Proses Atak di Harian Republika}

Berikut adalah alur kerja proses pengatakan koran di Harian Republika.

1. Pengolahan Naskah, Foto, dan Ilustrasi.

(1) Bahan utama sebuah berita ialah naskah dan atau foto. Naskah disediakan oleh wartawan atau reporter. Naskah dapat dilengkapi dengan foto. Foto tersebut dapat disediakan oleh wartawan atau reporter atau dapat juga diperoleh dari bank foto di redaksi. Foto dapat berupa foto berwarna ataupun foto hasil scan ataupun ilustrasi yang sengaja dibuat yang harus diolah lebih lanjut agar sesuai kebutuhan.

(2) Naskah yang dibuat oleh wartawan atau reporter diberikan kepada redaktur. Naskah diseleksi oleh redaktur. Redaktur lalu mengirimkan naskah tersebut ke bagian editor bahasa. Editor bahasa mengedit naskah dari segi ejaan dan tata bahasa. Dari editor, naskah dikirim ke bank data (terminal).
(3) Foto yang diambil oleh fotografer di lapangan untuk gambaran langsung berita, diberikan ke bagian olah foto. Biasanya satu naskah diberikan beberapa foto oleh Redaktur. Di bagian olah foto, foto tersebut diatur resolusi, cahaya, dan kontras. Dari sana, foto di kirim ke bank data (terminal).

(4) Jika tidak dilengkapi foto dan tidak tersedia di bank foto, redaktur memberikan naskah kepada ilustrator untuk dibuatkan ilustrasi yang sesuai dengan naskah. Ilustrasi yang dihasilkan ilustrator (biasanya beberapa ilustrasi) diberikan ke bagian olah foto untuk dipindai (scan), diatur resolusi, dan diberikan warna pada gambar ilustrasi tersebut dengan menggunakan software Adobe Photoshop. Hasilnya dikirim ke bank data (terminal).

2. Proses Mengatak (layout)

Setelah ketiga pengolahan di atas masuk ke terminal, penata letak mengambil naskah di terminal data tersebut, lalu menatanya di software Adobe InDesign. Dalam mengatak, penata letak melakukan langkahlangkah: membuat dummy, mengatur ukuran layout, dan mengatur komposisi naskah.

(1) Dummy yang dimaksud disini ialah sebuah partitur 
untuk halaman koran yang berisi iklan dan jumlah karakter untuk naskah headline dan box.

(2) Membuat Dokumen Baru, untuk mengatur ukuran atak atau membuat dokumen baru, dengan cara CTRL+N atau Command $+\mathrm{N}$ atau File $>$ New $>$ Document. Setelah itu diatur sesuai gaya selingkung perusahaan. Ukuran layout di bawah ini sudah ditetapkan dari sebelumnya atas kesepakatan penerbit Harian Republika.

Paper Size : $320 \mathrm{~mm} \mathrm{X}$ $578 \mathrm{~mm}$

Margin $\quad$ : Top : 17,5

$\mathrm{mm}$

Buttom : $17,5 \mathrm{~mm}$

Inside $\quad: 13 \mathrm{~mm}$

Outside $: 13 \mathrm{~mm}$

Column : 6

Gutter $\quad: 6 \mathrm{~mm}$

(3) Mengatur Komposisi Naskah Berdasarkan Gaya Selingkung

Berikut adalah beberapa hal yang harus diperhatikan ketika melakukan proses atak.

\section{Head Line}

a. Judul: paragraph style "000Judul 1" (warna disesuaikan desainer dan ukuran font diatas 60pt).

b. Byline: paragraph style "000Byline". Di awal diberikan huruf "n", lalu diubah dengan font dingbath (•).

c. Taiching: paragraph style "000Taiching-Lead".

d. Body Text : Menggunakan paragraph style "000-Body Text".

e. Untuk paragraf pertama diberikan drop cap 5 lines.

f. Initial : Menggunakan paragraph style "000-Initial". Di awal diberikan hurus "n", lalu diubah dengan font dingbath dan "ed:" diberikan family bold.

Foto : Menggunakan paragraph style "000-Kredit Foto" (letak disesuaikan dengan letakfoto).

Box/Tajuk (bawah)

a. Judul: paragraph style "000Judul2 R" (warna disesuaikan desainer dan ukuran font $33 \mathrm{pt}$ ).

b. Body Text: paragraph style "000-Body Box". Untuk paragraph pertama diberikan drop cap 3 lines.

c. Initial: paragraph style "000Initial". Di awal diberikan huruf "n", lalu diubah dengan font dingbath (-) dan "ed:" diberikan family font bold.

d. Foto: paragraph style "000Kredit Foto" (letak disesuaikan dengan letak foto).

Box/Tajuk (samping)

a. Judul: paragraph style "000Judul2 R" (warna disesuaikan desainer dan ukuran font diubah menjadi 24pt). 
b. Body Text: paragraph style "000-Body Box".

c. Initial: paragraph style "000Initial". Di awal diberikan huruf "n", lalu diubah dengan font dingbath (-) dan "ed:" diberikan family bold.

\section{Proses Pascaatak}

Hasil layout berupa satu halaman koran kemudian dicetak dicetak dalam ukuran A3 untuk dikoreksi oleh Redaktur. Perubahan atau kesalahan yang dikoreksi redaktur dikembalikan ke penata letak. Penata letak mengubah kembali desain tersebut agar sesuai dengan koreksi dari redaktur. Setelah sesuai dan tidak ada kesalahan atau perubahan, penata letak meminta Redaktur menyetujui desain tersebut untuk dikirim ke Bagian Pracetak.

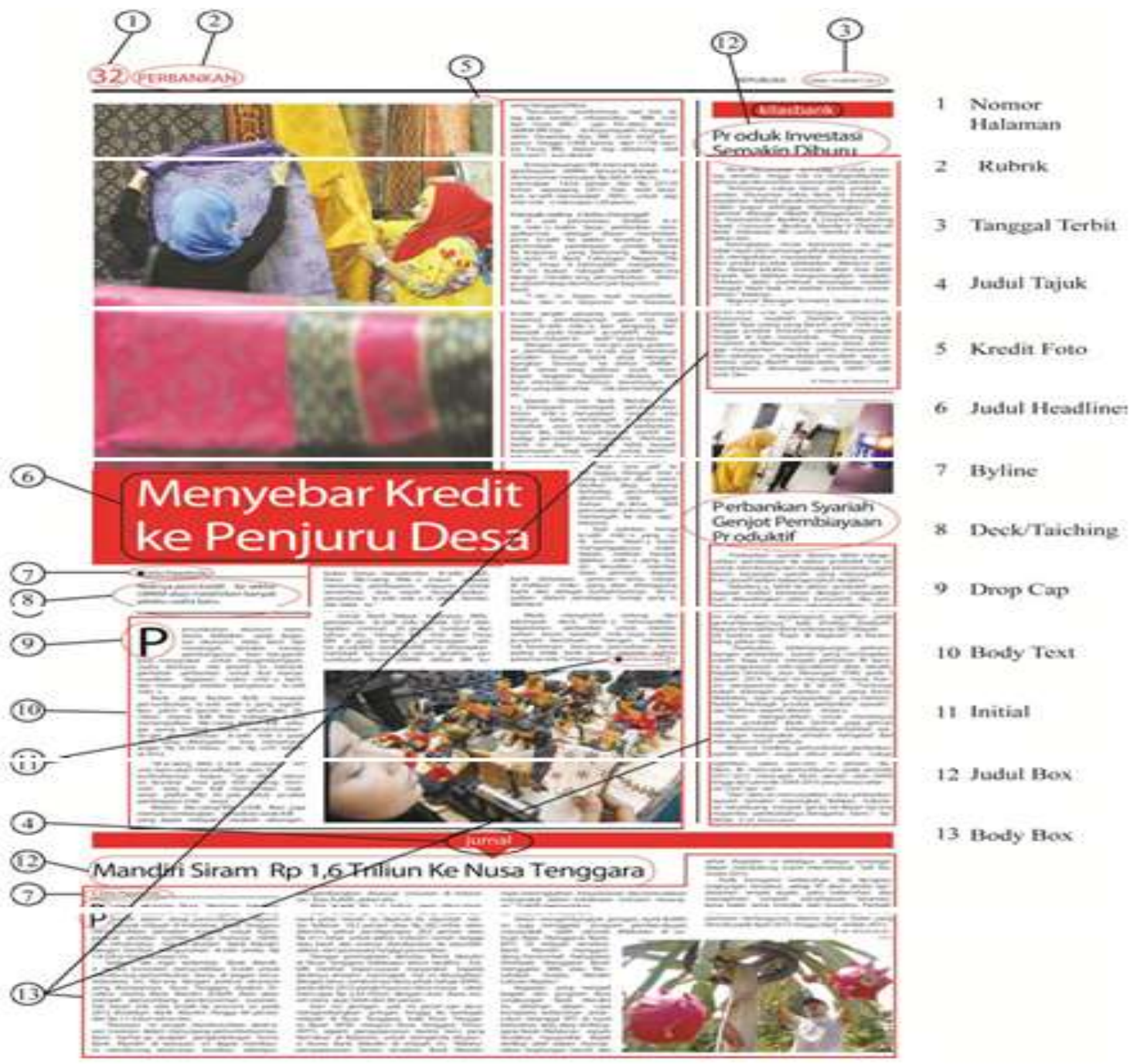

Gambar 1. Format Atak Keseluruhan 


\section{Pembahasan}

Bekerja di surat kabar harian berarti bekerja dengan target deadline. Artinya, segala sesuatu yang dilakukan seharusnya sudah tertentu dari segi waktu. Saat praktik industri di Harian Umum Republika, penulis menemukan beberapa masalah yang turut menghambat kelancaran proses atak.

\section{Masalah dalam Proses Me-layout}

Berikut adalah beberapa masalah yang ditemukan ketika proses me-layout koran di Harian Republika: waktu, pemilihan foto, pemenggalan kata, dan penempatan foto.

(1) Pemilihan Foto

Proses pemilihan foto merupakan inisiatif penata letak karena penata letak yang memilih foto yang diberikan oleh redaktur. Seharusnya, penata letak mempunyai wewenang untuk memilih foto yang terbaik dari beberapa pilihan yang diberikan redaktur untuk diletakkan dalam mengatak sebuah halaman koran. Ada baiknya sebelum dimasukkan dalam atak, penata letak bertanya terlebih dahulu ke redaktur untuk pemilihan foto. Karena terkadang keinginan redaktur tidak sesuai dengan pilihan penata letak. Jika sudah terlanjur memilih foto, tetapi redaktur tidak menyetujuinya, penata letak haus mengubah semuanya, baik naskah, judul, ukuran foto, dan sebagainya.

Jika harus memilih dua dari lima foto seperti di atas, inisiatif penata letak harus tepat, yaitu memilih foto yang terbaik dari kelima foto tersebut. Satu foto untuk foto utama dan satu untuk foto pendukung.

(2) Pemenggalan Kata

Ejaan adalah kaidah-kaidah cara menggambarkan bunyi-bunyi (kata, kalimat, dsb) bentuk tulisan (huruf-huruf) serta penggunaan tanda baca. Dalam softwere Adobe InDesign disebut dengan Hypernation. Jika dengan menual, ejaan atau pemenggalan kata bisa dilakukan dengan cara Command+(). Hal ini dilakukan agar tidak ada ruang kosong di setiap baris naskah. Juga dapat menaikkan naskah yang lebih di area atak.

(3) Penempatan Foto

Dalam penempatan foto, diperlukan kepantasan dan keseimbangan antara foto, judul, dan naskah. Tidak ada aturan dalam penempatan foto di sebuah halaman koran. Tetapi hanyalah kepantasan dan keseimbangan saja yang diperkirakan agar foto terlihat baik (tidak berantakan dan tidak menumpuk). Untuk ukuran, foto disesuaikan dengan banyaknya kolom yang disediakan dari naskah berita tersebut. Bisa dimaksimalkan dengan kolom yang ada, juga bisa kurang dari kolom yang disediakan. Menarik tidaknya layout yang berkaitan dengan foto bergantung pada kreativitas dan inisiatif penata letak. Namun, jika telah selesai dikerjakan dan hasilnya dikirim ke Redaktur, hasil tersebut belum tentu 
berterima oleh Redaktur. Jika ada koreksi, penata letak harus bekerja kembali sampai sesuai keinginan Redaktur.

(4) Kesalahan Editor Bahasa dan Redaktur

Untuk pengolahan naskah, seharusnya naskah yang sudah di edit dan dikirim ke terminal sudah tidak ada lagi kesalahan. Sebab masih banyak kesalahan penulisan dan struktur kalimat yang tidak sesuai ditemukan saat redaktur mengkoreksi hasil desain dari penata letak. Hal ini menyebabkan penambahan pekerjaan untuk layouter, karena penata letak yang harus mengubah kesalahankesalahan yang tidak seharusnya ada disaat redaktur mengoreksi desain.

Di alur pengolahan foto, redaktur terkadang tidak melewati alur kerja yang semestinya. Redaktur langsung mengirimkan foto ke pihak desain atau langsung mengirim foto ke terminal. Kejadian ini menyebabkan ketidak sesuaian ukuran foto yang akan di tata oleh penata letak dan menambah pekerjaan penata letak untuk mengolah foto tersebut yang seharusnya dikerjakan oleh bagian olah foto.

\section{Pemecahan Masalah}

Kendala yang dihadapi seorang penata letak, yaitu: kecepatan, ketepatan, dan keseimbangan. Ketiga kendala tersebut dapat memakan waktu dalam menata di area desain. Oleh karena itu, penata letak harus menguasai softwere Adobe InDesign dan mengetahui keunggulan dari softwere ini. Dengan menguasai dan mampu menerapkan keunggulan softwere Adobe InDesign, proses mengatak dapat dengan cepat ditata dan diselesaikan tanpa mengabaikan prinsip-prinsip dalam mengatak.

Berkaitan dengan pemilihan foto, ada baiknya sebelum dimasukan dalam proses layout, seorang layouter bertanya terlebih dahulu ke Redaktur untuk memastikan foto mana yang akan digunakan. Hal ini juga untuk menghemat waktu agar tidak ada ralat ketika layouter telah menyelesaikan tugasnya. Berkaitan dengan pemenggalan kata, kemampuan seorang layouter dalam menguasai softwere sangat diperlukan. Hal pertama yang harus dilakukannya ialah mengubah bahasa di paragraph style di Adobe InDesign yang sebelumnya menggunakan bahasa "Hebrew" ke bahasa "Spanish".

Bahasa Spanish memiliki sistem pemenggalan kata yang lebih mendekati ke bahasa Indonesia. Perubahan ini dapat mempercepat proses pemenggalan kata yang biasa dilakukan secara manual (command+(-)) oleh piñata letak. Keunggulan softwere Adobe Indesign harus dimanfaatkan karena dapat mempercepat proses atak. Salah satu cara ialah menghubungkan paragraph style sesuai dengan urutan naskah. Misalnya, menghubungkan judul ke byline, lalu menghubungkan byline ke taiching, selanjutnya 
menghubungkan taiching ke bodytext, dan seterusnya seperti itu sampai ke yang paling akhir (initial). Proses penghubungan ini harus per berita, tidak bisa dipakai untuk berita yang berbeda. Harus dibuat untuk headline, box bawah, dan box samping. Dengan cara ini, piñata letak bisa mempersingkat waktu karena hanya mem-block naskah, lalu klik kanan pada paragraph style penghubung yang pertama, setelah itu pilih "apply than next style". Naskah yang di-block, akan berubah sesuai dengan paragraph style yang sudah dihubungkan.

Berkaitan dengan naskah yang siap di-layout, naskah yang telah diedit oleh editor seharusnya dikembalikan ke Redaktur untuk mendapatkan persetujuan Redaktur. Jika telah disetujui Redaktur, naskah tersebut boleh dikirim ke Terminal sehingga tidak ada lagi koreksi jika telah di atak.

Berkaitan dengan proses kerja yang menjadi tanggung jawab Redaktur, Redaktur harus bekerja sesuai prosedur baku, misalnya tidak langsung mengirimkan foto ke Terminal tanpa melewati bagian olah foto. Redaktur juga sebaiknya memeriksa kembali naskah setelah diedit oleh editor.

\section{PENUTUP}

Untuk mengejar deadline di sebuah koran yang terbit harian, dibutuhkan kecepatan, kecekatan, dan kecermatan dari semua unsur yang terlibat dalam proses atak agar tidak ada kesalahan dalam mengatak.
Kesimpulan ini diperoleh dari hasil pembahasan proses atak di Harian Republika.

1. Bekerja di koran harian artinya bekerja dikejar deadline. Dengan demikian dibutuhkan staf yang benar-benar menguasai tugas dan fungsinya termasuk penguasaan softwere. Hal ini yang belum tampak diterapkan secara maksimal sehingga terjadi pemborosan waktu.

2. Penata letak yang bertanggung jawab memilih foto dari sejumlah foto yang tersedia di Terminal masih harus mengulang pekerjaannya jika hasil kerjanya tidak disetujui Redaktur.

3. Akibat dari masih kurangnya kemampuan penata letak dalam penguasaan software, masih terdapat kesalahan pemenggalan kata atau adanya bidang kosong antarkata yang cukup besar.

4. Masih terdapat kelemahan dalam proses pengolahan naskah dan foto, yaitu (1) editor tidak mengembalikan naskah yang diterima kepada redaktur tetapi langsung dikirim ke Terminal, (2) Redaktur kadang kala mengirim foto langsung ke Terminal tanpa melalui bagian olah foto.

\section{DAFTAR RUJUKAN}

Darmanto, Nova. 2007. Pengetahuan Penerbitan. Jakarta: Pusat Grafika Indonesia Depdiknas.

Hendratman, Hendi. 2006. Tips n Trix Computer Graphics 
Jurnal Publipreneur, Vol. 2, Nomor 4, Desember 2014, ISSN: 2338-5049

Design. Bandung: Informatika Bandung.

Kusrianto, Adi. 2004. Tipografi

Komputer untuk Desainer

Grafis. Yogyakarta: Penerbit Andi.

Rustan, Surianto. 2009. Layout Dasar \& Penerapannya.

Jakarta: Gramedia Pustaka Utama

Rustan, Surianto. 2011. Huruf, Font, Tipografi. Jakarta: Gramedia Pustaka Utama.
Sugengriadi. 1989. Peranan Editor dalam Penerbitan Buku dan Majalah. Jakarta: Balai Penerbit, FK UI.

Utomo, Punto Arif. 2010. Republika 17 Tahun Melintas Zaman. Jakarta: Harian Umum Republika.

http://tombaksada.webs.com/tentangt ataletak.htm. 20 Juni 2013 pukul 20.00 